\title{
Distribusi Suhu, Salinitas Dan Densitas Di Lapisan Homogen Dan Termoklin Perairan Selat Makassar
}

\author{
Tri Widya Laksana Putra*, Kunarso, A. Rita Tisisana Dwi K. \\ Program Studi Oseanografi, Fakultas Perikanan dan Ilmu Kelautan, Universitas Diponegoro \\ Jl. Prof. H. Sudarto, SH, Tembalang Semarang. 50275 Telp/fax (024)7474698 \\ Email :*triwilaputra@yahoo.com
}

\begin{abstract}
Abstrak
Selat Makassar merupakan salah satu celah penghubung antara Samudera Pasifik dan Samudera Hindia dengan karakteristik oseanografi lebih dipengaruhi oleh Samudera Pasifik melalui sirkulasi Arlindo. Sirkulasi Arlindo bersama dengan variasi pergerakan angin muson akan berpengaruh terhadap distribusi suhu, salinitas dan densitas di lapisan homogen dan termoklin. Penelitian ini bertujuan mengkaji distribusi suhu, salinitas dan densitas di lapisan homogen dan termoklin perairan Selat Makassar. Penelitian ini dilaksanakan pada bulan Oktober 2015. Data diperoleh dari Pusat Penelitian dan Pengembangan Sumber Daya Laut dan Pesisir (P3SDLP) dengan data primer berupa data suhu, salinitas, densitas dan kedalaman menggunakan instrumen CTD. Stasiun pengambilan data terdiri dari 18 stasiun pengambilan data berdasarkan metode purposive sampling. Data yang diperoleh kemudian dianalisis menggunakan metode analisis statistik deskriptif. Hasil menunjukkan bahwa ketebalan lapisan homogen antara 19,5-68,5 m. Ketebalan lapisan termoklin bervariasi antara 50-220 m. Variabilitas ketebalan lapisan homogen dan lapisan termoklin disebabkan beberapa faktor seperti tekanan angin, pemanasan matahari, transpor massa air, dan aktivitas gelombang internal. Sebaran nilai suhu di lapisan homogen bervariasi antara 25,35-29,94 ${ }^{\circ} \mathrm{C}$. Suhu permukaan laut cenderung lebih tinggi di bagian utara Selat Makassar. Suhu di lapisan termoklin berkisar antara 12,09-29,22 ${ }^{\circ} \mathrm{C}$. Salinitas di lapisan homogen bervariasi antara 33,91-34,59 \%o. Nilai salinitas permukaan laut cenderung lebih tinggi di selatan Selat Makassar. Hal ini diduga disebabkan pengaruh dari Laut Jawa dan Laut Flores. Salinitas di lapisan termoklin bervariasi antara $34,18-34,88 \%$. Nilai densitas di lapisan homogen bervariasi antara 20,93-22,93 kg/m ${ }^{3}$. Nilai densitas di lapisan termoklin bervariasi antara $21,47-26,13 \mathrm{~kg} / \mathrm{m}^{3}$. Gradien rata - rata temperatur lapisan termoklin antara $0,07-0,14$ ${ }^{\circ} \mathrm{C} / \mathrm{m}$. Gradien rata - rata temperatur berbanding terbalik dengan ketebalan lapisan termoklin.
\end{abstract}

Kata kunci: Arlindo, Lapisan Homogen, Selat Makassar, Termoklin

\begin{abstract}
Makassar Strait is a pathway that connected the Pacific Ocean and the Indian Ocean with oceanographic characteristics more influenced by the Pacific Ocean through Arlindo. Arlindo circulation and movement variations of the monsoon will affect the distribution of temperature, salinity and density in homogeneous and thermocline layer. The aims of this study is were to assess the distribution of temperature, salinity and density in homogeneous and thermocline layer of Makassar Strait. This research was conducted in October 2015. Data were obtained from the Pusat Penelitian dan Pengembangan Sumber Daya Laut dan Pesisir (P3SDLP) with the primary data that were temperature, salinity, density and depth by using CTD instruments. Data measurement station consists of 18 stations based on purposive sampling method. Data were analyzed using descriptive statistical analysis method. The results showed that the homogeneous layer thickness were vary with range from $19.5 \mathrm{~m}$ to $68.5 \mathrm{~m}$. Thermocline layer thickness between 50-220 m. Variability homogeneous layer thickness and the thermocline were caused by several factors such as air pressure, solar heating, water mass transport, and internal wave activity. The distribution of temperature in a homogeneous layer were vary with range from 25.35 ${ }^{\circ} \mathrm{C}$ to $29.94^{\circ} \mathrm{C}$. Sea-surface temperatures tend to be higher in the northern of Makassar Strait. Temperatures in the thermocline layer ranged from $12.09{ }^{\circ} \mathrm{C}$ to $29.22{ }^{\circ} \mathrm{C}$. Salinity in a homogeneous layer werer vary with range from $33.91 \%$ to $34.59 \%$. Sea surface salinity were higher in the southern of Makassar Strait. This was assumed due to the influence of the Java Sea and Flores Sea. Salinity in the thermocline layer were vary with range from $34.18 \%$ to $34.88 \%$. The density in a homogeneous layer vary among $20.93-22.93 \mathrm{~kg} / \mathrm{m}^{3}$. The density in the thermocline layer were vary with range from $21.47 \mathrm{~kg} / \mathrm{m}^{3}$ to $26.13 \mathrm{~kg} / \mathrm{m}^{3}$. Average gradient temperature of the thermocline layer were vary with range from $0.07{ }^{\circ} \mathrm{C} / \mathrm{m}$ to $0.14{ }^{\circ} \mathrm{C} / \mathrm{m}$. Average gradient of temperature was inversely proportional to the thickness of the thermocline layer.
\end{abstract}

Keywords: Arlindo, Homogeneous layer, Makassar Strait, Thermocline 


\section{PENDAHULUAN}

Perairan Indonesia secara geografis terletak diantara dua Samudra besar yaitu Samudra Pasifik dan Samudra Hindia. Kondisi ini membentuk suatu sistem sirkulasi lintasan massa air dari Samudra Pasifik ke Samudra Hindia. Sistem sirkulasi massa air hangat dari Samudra Pasifik menuju Samudra Hindia yang relatif dingin yang melawati perairan Indonesia, dikenal dengan arus lintas Indonesia (Arlindo) (Wyrtki 1961, Fieux et al., 1996). Arlindo terjadi karena muka air Samudra Pasifik lebih tinggi dari pada muka air Samudra Hindia. Hal ini menyebabkan terbentuknya gradien tekanan sehingga arus mengalir dari Samudra Pasifik ke Samudra Hindia (Wyrtki, 1987). Arus yang mengalir ini melewati beberapa wilayah di perairan Indonesia salah satunya adalah Selat Makassar. Selat Makassar merupakan lintasan utama Arlindo. Adapun Arlindo ini sendiri mengakibatkan terjadinya variasi parameter oseanografi secara vertikal dan horizontal di Selat Makassar.

Massa air yang mengalir di Selat Makassar melalui Arlindo merupakan massa air Samudra Pasifik bagian utara dan selatan. Berdasarkan analisis massa air di Selat Makassar, teridentifikasi massa air dari North Pacific Subtropical Water (NPSW) dengan salinitas maksimum (34,7 \%o) di atas lapisan termoklin ditandai yang sekarang disebut Air Sentral Pasifik Utara (North Pacific Central Water) dan Air Menengah Pasifik Utara (North Pacific Intermediate Water / NPIW) di bawah termoklin ditandai dengan salinitas minimum 34,45 \%o (Gordon, 1996). Stratifikasi kolom perairan Selat Makassar kemudian akan dipengaruhi oleh adanya kedua massa air tersebut.

Kondisi oseanografi di tiap lapisan perairan Selat Makassar selain dipengaruhi oleh massa air NPSW dan NPIW juga dipengaruhi oleh fenomena interaksi iklim dan laut. Pada musim timur, arah tekanan angin berlawanan dengan arah arus permukaan Selat Makassar sehingga akan menimbulkan efek stagnansi pada massa air lapisan atas. Interaksi yang terjadi mengakibatkan pola distribusi massa air tiap lapisan perairan Selat Makassar mengalami perbedaan distribusi massa air. Massa air lapisan tengah relatif lebih aktif dari pada distribusi massa air lapisan di atasnya (Wyrtki, 1961).

Selama angin musim timur, terjadi peningkatan salinitas akibat penguapan yang besar, ditambah dengan masuknya massa air yang mempunyai salinitas tinggi dari Samudra Pasifik melalui Laut Sulawesi dan masuk ke perairan Selat Makassar. Hembusan angin yang kuat menimbulkan suatu proses pengangkatan besar-besaran terhadap massa air laut sehingga bila disertai proses penaikan massa air dapat mengangkat unsur-unsur hara yang sangat diperlukan sebagai sumber makanan hayati ke permukaan (Wyrtki, 1961). Semua yang terjadi di permukaan akan mempengaruhi kondisi oseanografi kolom air lapisan homogen seperti suhu dan salinitas yang akan diikuti oleh perubahan sigma-t sebagai fungsi suhu dan salinitas.

Berdasarkan beberapa hal diatas maka interaksi iklim dan laut di Selat Makassar berpengaruh terhadap variabilitas massa air antar lapisan air laut khususnya lapisan homogen dan lapisan termoklin. Kajian mengenai distribusi massa air tiap lapisan perairan Selat Makassar penting dilakukan untuk mengetahui seberapa besar pengaruh interaksi iklim dan laut di perairan Selat Makassar pada saat Arlindo tertinggi.

\section{MATERI DAN METODE \\ Materi Penelitian}

Materi yang digunakan dalam penelitian ini terdiri dari data primer dan data sekunder. Data primer merupakan data yang diperoleh secara insitu pada survei tanggal 03-11 Oktober 2015 yang terdiri dari data suhu, salinitas, densitas, dan kedalaman Perairan Selat Makassar, Sulawesi. Data sekunder yang digunakan berupa peta Rupa Bumi Indonesia (RBI) dengan skala 1:25.000 yang dikeluarkan oleh BIG tahun 2001.

\section{Metode Penelitian}

Metode penelitian ini menggunakan metode kuantitatif, yang dapat diartikan sebagai metode ilmiah/scientific karena telah memenuhi kaidah-kaidah ilmiah yaitu konkret/empiris, obyektif, terukur, rasional, dan sistematis. Metode ini disebut kuantitatif karena data penelitian yang digunakan berupa angka-angka dan analisis menggunakan statistik (Sugiyono, 2009). Data yang diperoleh dari pengukuran dilapangan kemudian akan diolah untuk dilihat persebaran massa air di lapisan homogen 
dan lapisan termoklin. Untuk mengetahui pengaruh arlindo terhadap distribusi massa air dilapisan homogen dan termoklin digunakan pendekatan deskriptif terhadap data yang telah diolah.

\section{Metode Penentuan Lokasi}

Metode penentuan stasiun penelitian menggunakan metode purposive sampling. Lokasi ditentukan berdasarkan pertimbangan tertentu berdasarkan dari tujuan dan sasaran dilakukannya penelitian (Sugiyono, 2009). Penentuan titik stasiun pengukuran ditetapkan dari arah utara ke arah selatan perairan Selat Makassar, sebanyak 18 titik (Gambar 1). Pembagian titik stasiun didasarkan atas bentuk geografis Selat Makassar yaitu tersebar dari arah utara ke arah selatan Kemudian keseluruhan titik-titik stasiun dibagi menjadi tiga transek stasiun. Hal tersebut ditentukan berdasarkan pertimbangan meningkatkan akurasi interpolasi data di dalam pengolahan data oleh software Ocean Data View (ODV).

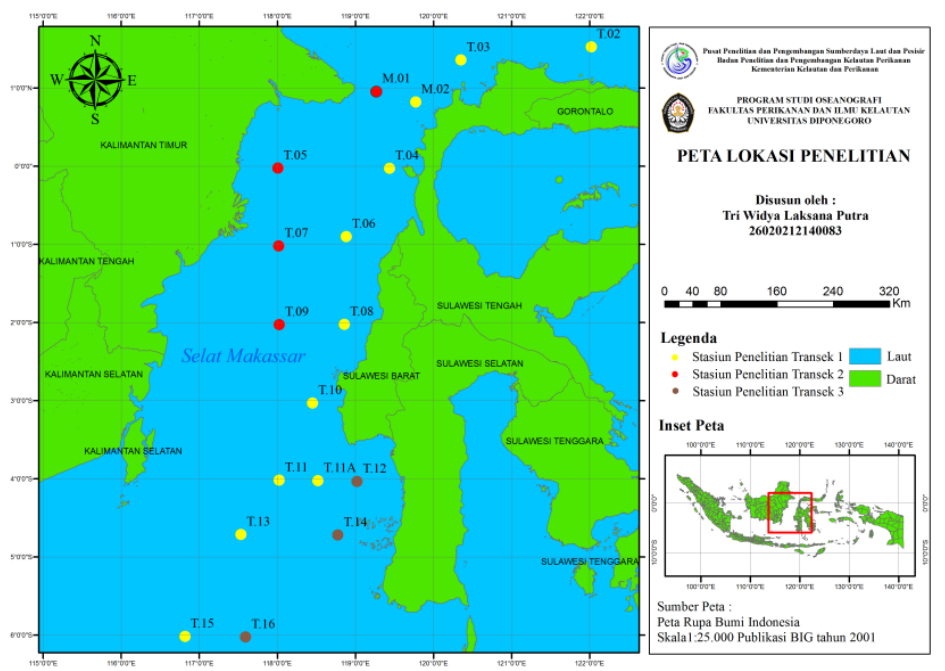

Gambar 1. Peta Lokasi Penelitian

\section{Metode Pengambilan Data}

Metode pengambilan data atau teknik sampling menggunakan teknik purposive sampling. Teknik ini merupakan metode teknik sampling non probability sampling (Sugiyono, 2009). Pengambilan data suhu, salinitas, densitas dan kedalaman diperoleh dari hasil pengukuran di lapangan (survei lapangan) oleh Pusat Penelitian dan Pengembangan Sumber Daya Laut dan Pesisir (P3SDLP), Badan Penelitian dan Pengembangan Kelautan dan Perikanan (Balitbang KP), Kementrian Kelautan dan Perikanan (KKP), dengan menggunakan CTD (Conductivity Temperature Depth). CTD memiliki tiga sensor utama, yakni sensor tekanan, sensor temperatur, dan sensor untuk mengetahui daya hantar listrik air laut (konduktivitas). Pengukuran tekanan pada CTD menggunakan strain gauge pressure monitor atau quartz crystal.

Data peta Rupa Bumi Indonesia merupakan data sekunder yang diperoleh dari instansi terkait untuk melengkapi data yang diperoleh dari survey lapangan. Data sekunder tersebut diperoleh dari Bakosurtanal berupa Peta Rupa Bumi Indonesia skala 1 : 500.000 tahun 2001.

\section{Metode Pengolahan Data dengan Ocean Data View (ODV)}

Data salinitas, suhu dan kedalaman dalam format ASCII kemudian data tersebut menjadi data masukan untuk diolah di program Ms. Excel. Hasil pengolahan Ms. Excel menjadi data masukan untuk diolah di software ODV. Dari pengolahan ODV akan didapatkan hasil output data sebaran vertikal (berupa grafik menegak) dan bagian vertikal (irisan melintang).

\section{Metode Penentuan Batas Atas dan Batas Bawah Lapisan Termoklin}


Ross (1970) mendefinisikan lapisan termoklin sebagai suatu kedalaman atau posisi dengan gradien temperatur lebih besar atau sama dengan $0,1^{\circ} \mathrm{C} / \mathrm{m}$. Berdasarkan definisi tersebut maka kedalaman batas atas dan batas bawah lapisan termoklin dapat ditentukan.

Formulasi untuk mencari kedalaman lapisan termoklin menurut Stern (1975) adalah :

$$
\mathrm{H}=\{\Delta \mathrm{T} /(\max \partial \mathrm{T}(\mathrm{z}) / \partial \mathrm{z})\}
$$

Keterangan :

$\mathrm{H}=$ kedalaman lapisan termoklin

$\Delta \mathrm{T}=$ gradien temperatur

$\partial \mathrm{T}(\mathrm{z}) / \partial \mathrm{z})=$ perubahan temperatur terhadap kedalaman

Nilai perubahan temperatur terhadap kedalaman $[\partial \mathrm{T}(\mathrm{z}) / \partial \mathrm{z})]$ yaitu perubahan termperatur sebesar $\geq 0,1^{\circ} \mathrm{C} / \mathrm{m}$ (Ross, 1970).

Menghitung gradien temperatur vertikal berdasarkan formulasi yang digunakan Song et al., (2007) :

$$
G_{j}=\frac{T_{j+1}-T_{j}}{D_{j+1}-D_{j}}
$$

Keterangan: $G_{j}$ merupakan gradien temperatur antara $D_{j}$ dan $D_{j+1}$.

(Song et al., 2007)

Setelah nilai gradien didapat maka kedalaman batas atas dan batas bawah lapisan termoklin dapat ditentukan. Batas atas yaitu kedalaman minimum yang sudah terjadi perbedaan temperatur lebih besar atau sama dengan $0,1^{\circ} \mathrm{C} / \mathrm{m}$ dengan kedalaman dibawahnya, sedangkan batas bawahnya adalah batas akhir yang masih terdapat perbedaan lebih besar atau sama dengan $0,1^{\circ} \mathrm{C} / \mathrm{m}$ dengan kedalaman diatasnya, namun sudah tidak terjadi $0,1^{\circ} \mathrm{C} / \mathrm{m}$ dengan kedalaman dibawahnya. Jika pada lapisan ini terdapat gradien temperatur yang kurang dari $0,1^{\circ} \mathrm{C} / \mathrm{m}$, maka dilihat gradien temperatur di atas dan di bawahnya, apabila di atas dan di bawahnya masih lebih besar dari $0,1^{\circ} \mathrm{C} / \mathrm{m}$ maka lapisan ini tetap digabungkan sebagai lapisan termoklin.

\section{Metode Analisis Data}

Analisis yang digunakan adalah analisis statistik deskriptif, yaitu statistik yang digunakan untuk menganalisis data dengan cara mendeskripsikan atau menggambarkan data yang telah terkumpul sebagaimana adanya tanpa bermaksud membuat kesimpulan yang berlaku untuk umum atau generalisasi (Sugiyono, 2011).

\section{HASIL}

\section{Gradien Temperatur}

\begin{tabular}{|c|c|c|c|c|c|c|c|c|c|c|}
\hline \multirow{3}{*}{ No } & \multirow{3}{*}{ Transek } & \multicolumn{5}{|c|}{ Gradien Temperatur } & \multicolumn{4}{|c|}{ Gradien Rata - Rata Temperatur } \\
\hline & & Minimum & Stasiun & Maksimum & Stasiun & Rata - rata & Minimum & Stasiun & Maksimum & Stasiun \\
\hline & & $\left({ }^{\circ} \mathrm{C} / \mathrm{m}\right)$ & & $\left({ }^{\circ} \mathrm{C} / \mathrm{m}\right)$ & & $\left({ }^{\circ} \mathrm{C} / \mathrm{m}\right)$ & $\left({ }^{\circ} \mathrm{C} / \mathrm{m}\right)$ & & $\left({ }^{\circ} \mathrm{C} / \mathrm{m}\right)$ & \\
\hline 1 & 1 & 0,005 & Timit 03 & 0,3 & Timit 03 & 0,1 & 0,07 & Mooring 02 & 0,14 & Timit 15 \\
\hline 2 & 2 & 0,01 & Timit 07 & 0,26 & Timit 05 & 0,09 & 0,08 & Mooring 01 & 0,09 & Timit 07 \\
\hline 3 & 3 & 0,007 & Timit 14 & 0,25 & Timit 14 & 0,11 & 0,07 & Timit 14 & 0,15 & Timit 16 \\
\hline
\end{tabular}

Tabel 1. Gradien Temperatur Lapisan Termoklin

\section{Lapisan Homogen dan Termoklin}

Berdasarkan pengolahan gradien temperatur maka dapat ditentukan stratifikasi kolom perairan. Batas bawah lapisan homogen atau dapat dikatakan kedalaman lapisan termoklin transek 1 antara 27,5 $\mathrm{m}$ hingga 67,5 m (Gambar 4). Kedalaman lapisan termoklin transek 1 antara 27,5 m (Timit 03, 04 dan 08) hingga 67,5 m (Timit 02,11 dan 11A), kedalaman lapisan termoklin transek 2 antara 19,5 m (Timit 09) hingga 48,5 m (Timit 07) dan kedalaman lapisan termoklin transek 3 antara 26,5 m (Timit 14) hingga 68,5 (Timit 16) (Tabel 2) 
(a)

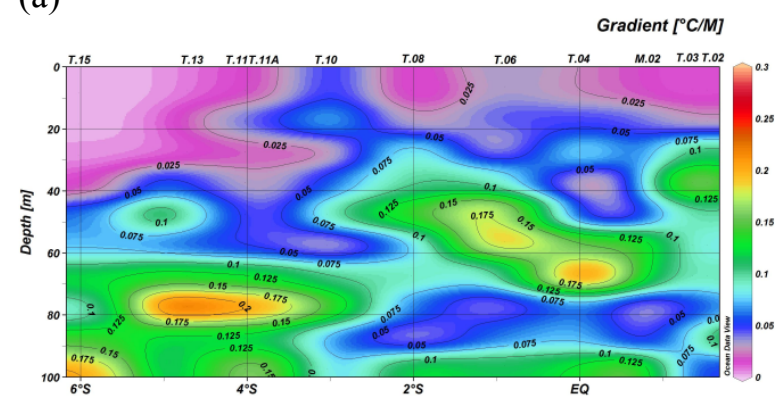

(c)

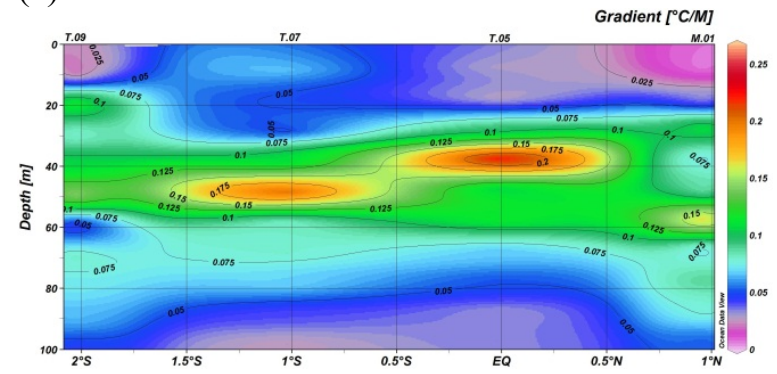

(e)

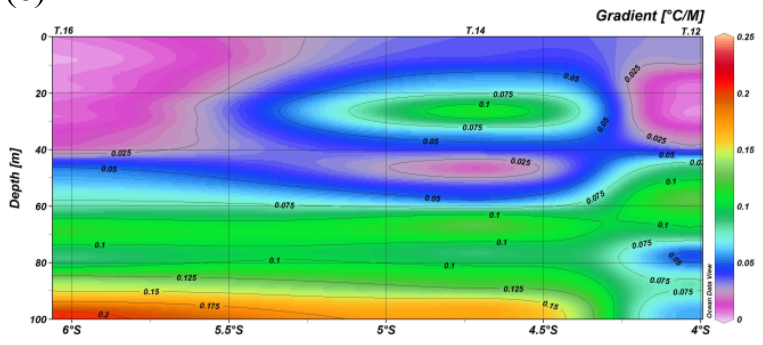

(b)

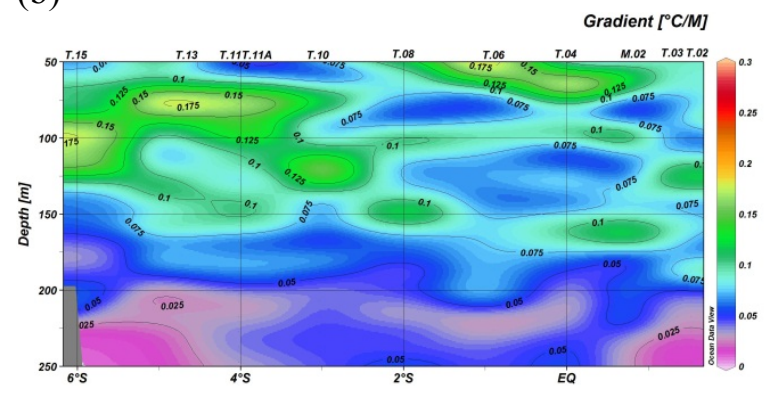

(d)

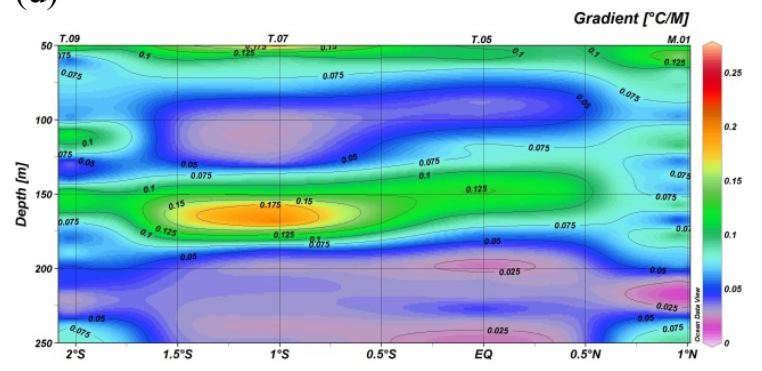

(f)

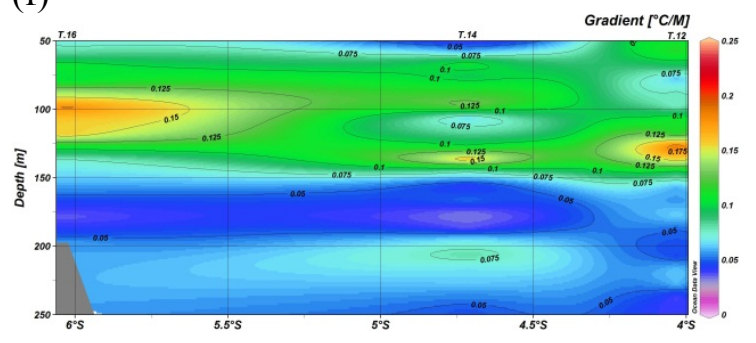

Gambar 2. Sebaran gradien temperatur lapisan homogen transek 1 kedalaman 0-100 m (a). Sebaran gradien temperatur lapisan termoklin transek 1 kedalaman 50-250 m (b). Sebaran gradien temperatur lapisan homogen transek 2 kedalaman 0-100 m (c). Sebaran gradien temperatur lapisan termoklin transek 2 kedalaman 50-250 m (d). Sebaran gradien temperatur lapisan homogen transek 3 kedalaman 0-100 m (e). Sebaran gradien temperatur lapisan termoklin transek 3 kedalaman 50-250 m (f).

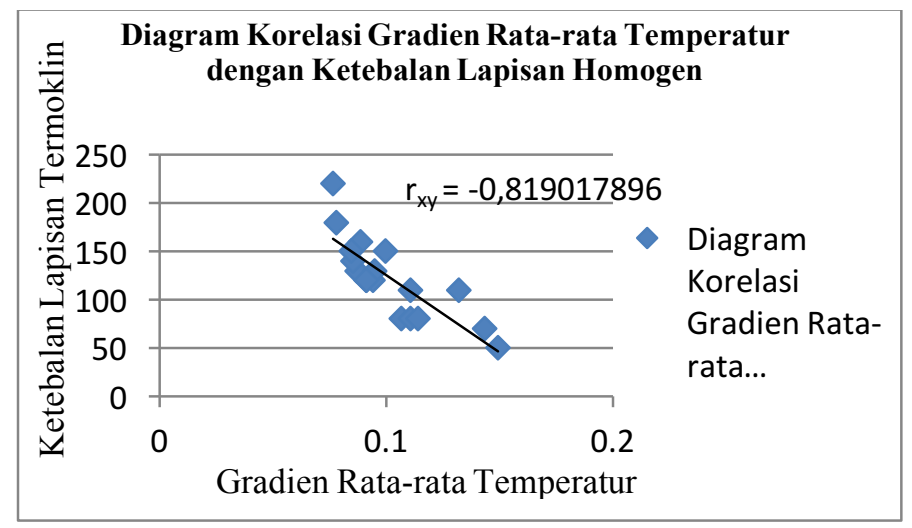

Gambar 3. Diagram korelasi antara gradien rata-rata temperatur dengan ketebalan lapisan termoklin 
Tabel 2. Tabel Lapisan Homogen

\begin{tabular}{|c|c|c|c|c|c|}
\hline \multirow{4}{*}{ Transek } & \multicolumn{5}{|c|}{ Lapisan Homogen } \\
\hline & \multicolumn{5}{|c|}{ Sebaran Batas Bawah } \\
\hline & Minimum & Stasiun & Maksimum & Stasiun & Rata - rata \\
\hline & (m) & & (m) & & (m) \\
\hline 1 & 27,5 & $\begin{array}{l}\text { Timit } 03 \text {, Timit } \\
04 \text {, dan Timit } 08\end{array}$ & 67,5 & $\begin{array}{c}\text { Timit } 02 \text {, Timit } \\
11 \text { dan Timit } \\
11 \mathrm{~A}\end{array}$ & 49,4 \\
\hline 2 & 19,5 & Timit 09 & 48,5 & Timit 07 & 33,25 \\
\hline 3 & 26,5 & Timit 14 & 68,5 & Timit 16 & 50,83 \\
\hline
\end{tabular}

Tabel 3. Tabel Lapisan Termoklin

\begin{tabular}{|c|c|c|c|c|c|c|c|c|c|c|}
\hline \multirow{4}{*}{ Transek } & \multicolumn{10}{|c|}{ Lapisan Termoklin } \\
\hline & \multicolumn{5}{|c|}{ Sebaran Batas Bawah } & \multicolumn{5}{|c|}{ Ketebalan } \\
\hline & Minimum & Stasiun & Maksimum & Stasiun & Rata - Rata & Minimum & Stasiun & Maksimum & Stasiun & Rata-rata \\
\hline & (m) & & (m) & & (m) & (m) & & (m) & & (m) \\
\hline \multirow[t]{2}{*}{1} & 127,5 & Timit & 277,5 & Mooring & 172,13 & 70 & Timit & 220 & Mooring & 122,72 \\
\hline & & 10 & & 02 & & & 15 & & 02 & \\
\hline \multirow[t]{2}{*}{2} & 157,5 & Timit & 178,5 & Timit 07 & 168,25 & 120 & Timit & 150 & Mooring & 135 \\
\hline & & 05 & & & & & 05 & & 01 & \\
\hline \multirow[t]{2}{*}{3} & 118,5 & Timit & 206,5 & Timit 14 & 154,16 & 50 & Timit & 180 & Timit 14 & 103,33 \\
\hline & & 16 & & & & & 16 & & & \\
\hline
\end{tabular}

Sebaran batas bawah lapisan termoklin transek 1 terdeteksi dari kedalaman 127,5 m (Timit 10) hingga 277,5 m (Mooring 02), transek 2 terdeteksi dari kedalaman 157,5 m (Timit 05) hingga 178,5 m (Timit 07), transek 3 terdeteksi dari kedalaman 118,5 m (Timit 16) hingga 206,5 m (Timit 14) (Tabel 3). Nilai sebaran batas bawah dan sebaran batas atas lapisan termoklin menciptakan selisih kedalaman atau dapat diketahui sebagai ketebalan lapisan termoklin. Ketebalan lapisan termoklin sangat bervariasi setiap stasiun. Ketebalan lapisan termoklin di transek 1 bervariasi antara $70 \mathrm{~m}$ (Timit 15) hingga $220 \mathrm{~m}$ (Mooring 02), ketebalan lapisan termoklin transek 2 antara $120 \mathrm{~m}$ (Timit 05) hingga $150 \mathrm{~m}$ (Mooring 01), ketebalan lapisan termoklin transek 3 antara $50 \mathrm{~m}$ (Timit 16) sampai $180 \mathrm{~m}$ (Timit 14) (Tabel 3).

\section{Distribusi Suhu}

Nilai suhu di lapisan homogen transek 1 berkisar antara $25,35{ }^{\circ} \mathrm{C}$ (Timit 02) hingga $29,94{ }^{\circ} \mathrm{C}$ (Timit 04), sebaran suhu di lapisan homogen transek 2 antara $27,66{ }^{\circ} \mathrm{C}$ (Timit 07) hingga $29,5{ }^{\circ} \mathrm{C}$ (Timit 07) dan sebaran suhu di lapisan homogen transek 3 antara $26,05{ }^{\circ} \mathrm{C}$ (Timit 16) hingga $28,9{ }^{\circ} \mathrm{C}$ (Timit 14).

Pada lapisan termoklin transek 1 suhu bervariasi antara $12.09{ }^{\circ} \mathrm{C}$ (Mooring 02) hingga $29.2{ }^{\circ} \mathrm{C}$ (Timit 03), sebaran suhu di lapisan termoklin transek 2 antara $14.04{ }^{\circ} \mathrm{C}$ (Timit 07) hingga $29,21{ }^{\circ} \mathrm{C}$ (Timit 09) dan sebaran suhu di lapisan termoklin transek 3 antara $13,98{ }^{\circ} \mathrm{C}$ (Timit 14) hingga $27,98{ }^{\circ} \mathrm{C}$ (Timit 14). 


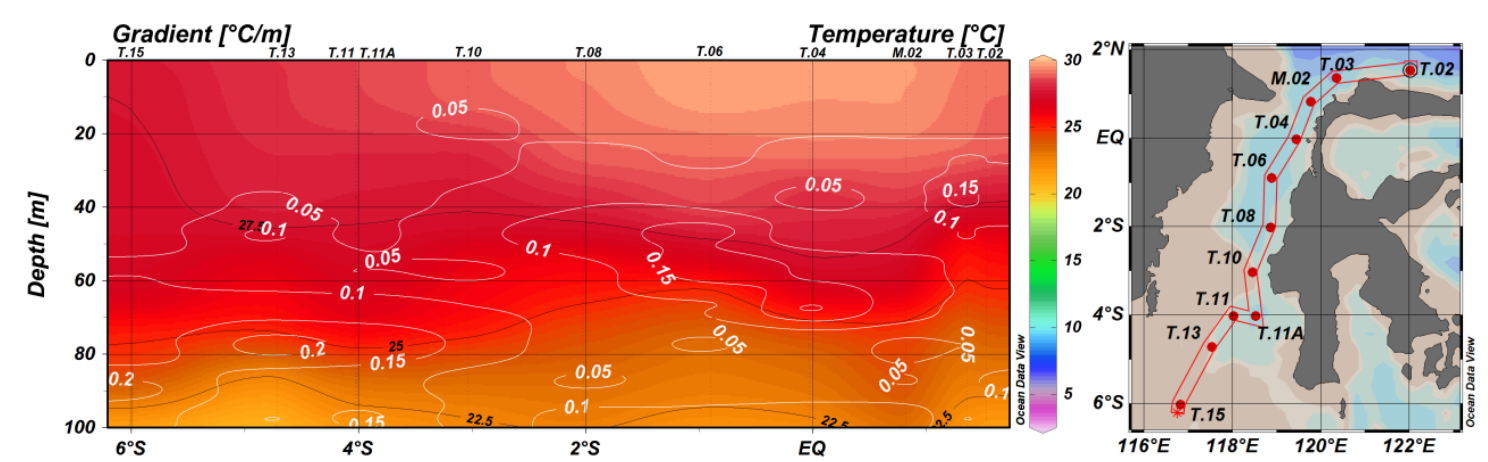

Gambar 4. Overlay profil vertikal suhu di lapisan homogen dengan gradien temperatur di lapisan homogen

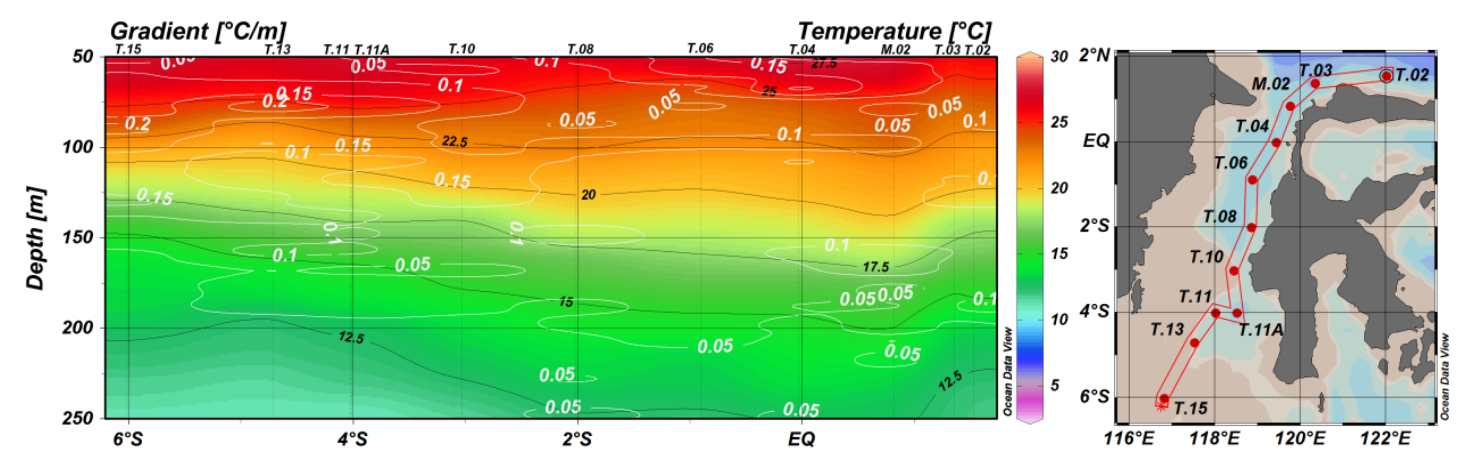

Gambar 5. Overlay profil vertikal suhu di lapisan termoklin dengan gradien temperatur di lapisan termoklin

\section{Distribusi Salinitas}

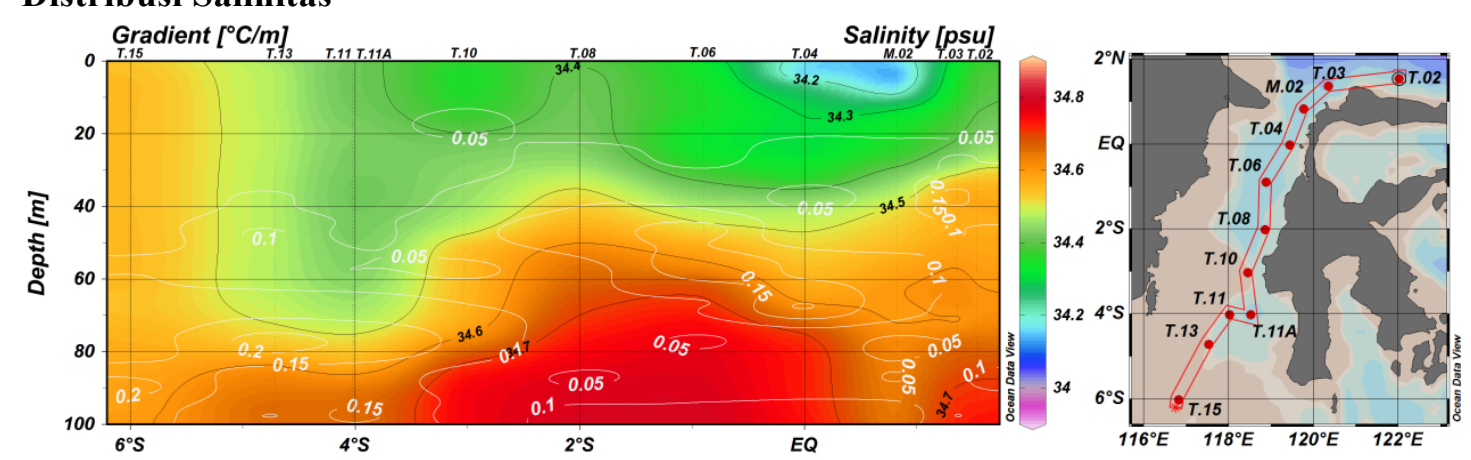

Gambar 6. Overlay profil vertikal salinitas di lapisan homogen dengan gradien temperatur di lapisan homogen

Nilai salinitas di lapisan homogen transek 1 bervariasi antara33.9 \%o (Timit 04) hingga $34.59 \%$ (Timit 02), nilai salinitas di lapisan homogen transek 2 antara 33,92 \%o (Mooring 01) hingga 34,34 \%o (Mooring 01), dan nilai slainitas di lapisan homogen transek 3 antara 34,37 \%o (Timit 14) hingga 34,58 \%o (Timit 12).

Pada lapisan termoklin transek 1 nilai salinitas bervariasi antara 34,19 \%o (Timit 04) hingga $34,84 \%$ (Timit 08), sebaran nilai salinitas di lapisan termoklin transek 2 antara 34,18 \%o (Mooring 01) hingga 34,88 \%o (Timit 09), dan sebaran nilai salinitas di lapisan termoklin transek 3 antara 34,35 \%o (Timit 14) hingga 34,77 \%o (Timit 14). 


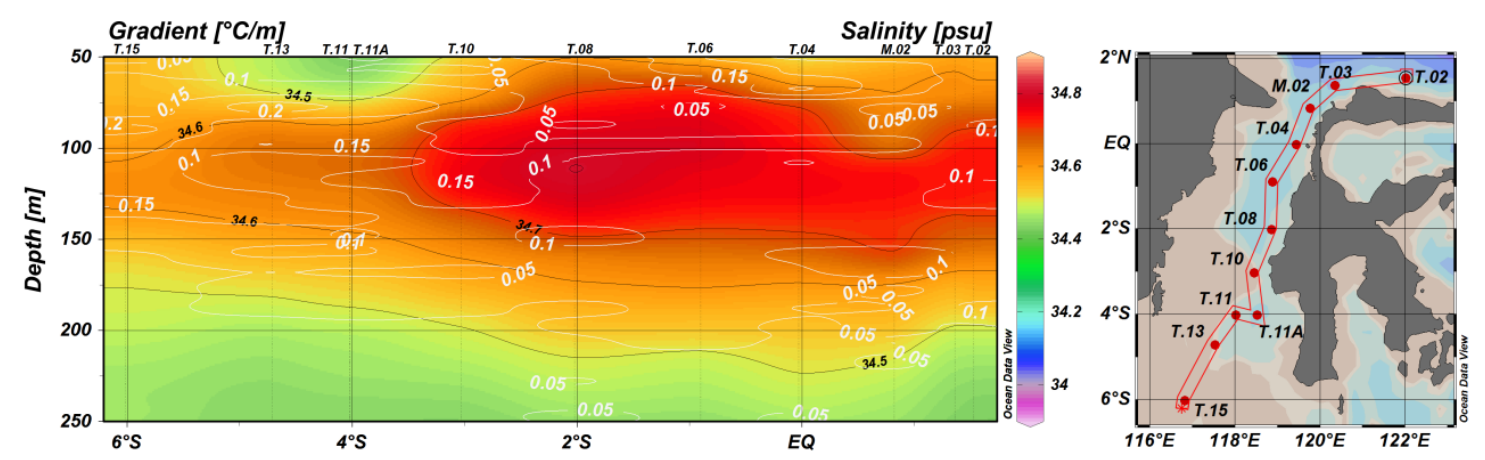

Gambar 7. Overlay profil vertikal salinitas di lapisan termoklin dengan gradien temperatur di lapisan termoklin

\section{Distibusi Densitas}

Distribusi densitas di lapisan homogen transek 1 bervariasi antara $20,93 \mathrm{~kg} / \mathrm{m}^{3}$ (Timit 04) hingga $22,93 \mathrm{~kg} / \mathrm{m}^{3}$ (Timit 02), sebaran densitas di lapisan homogen transek 2 antara $21,15 \mathrm{~kg} / \mathrm{m}^{3}$ (Timit 07) hinga $21,93 \mathrm{~kg} / \mathrm{m}^{3}$ (Timit 07), dan sebaran densitas di lapisan homogen transek 3 antara $21,63 \mathrm{~kg} / \mathrm{m}^{3}$ (Timit 14) hingga $22,69 \mathrm{~kg} / \mathrm{m}^{3}$ (Tiimt 16 ).

Distribusi densitas di lapisan termoklin transek 1 bervariasi antara $21,53 \mathrm{~kg} / \mathrm{m}^{3}$ (Timit 03) hingga $26,13 \mathrm{~kg} / \mathrm{m}^{3}$ (Mooring 02), sebaran densitas di lapisan termoklin transek 2 antara $21,47 \mathrm{~kg} / \mathrm{m}^{3}$ (Timit 09) hingga $25,82 \mathrm{~kg} / \mathrm{m}^{3}$ (Timit 07), dan sebaran densitas di lapisan termoklin transek 3 antara $21,91 \mathrm{~kg} / \mathrm{m}^{3}$ (Timit 14) hingga $25,82 \mathrm{~kg} / \mathrm{m}^{3}$ (Timit 14 ).

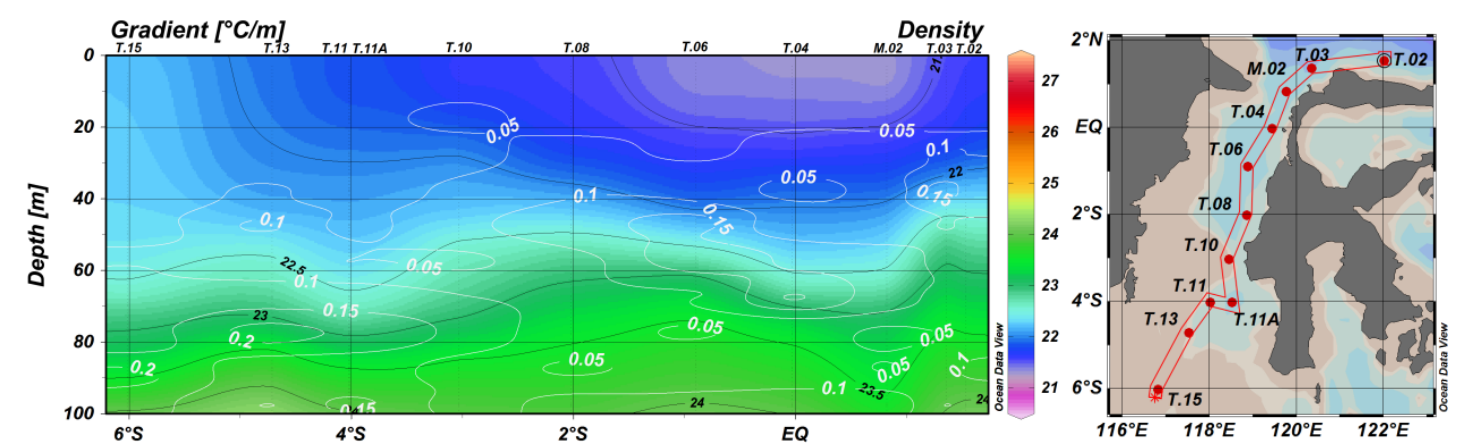

Gambar 8. Overlay profil vertikal densitas di lapisan homogen dengan gradien temperatur di lapisan homogen

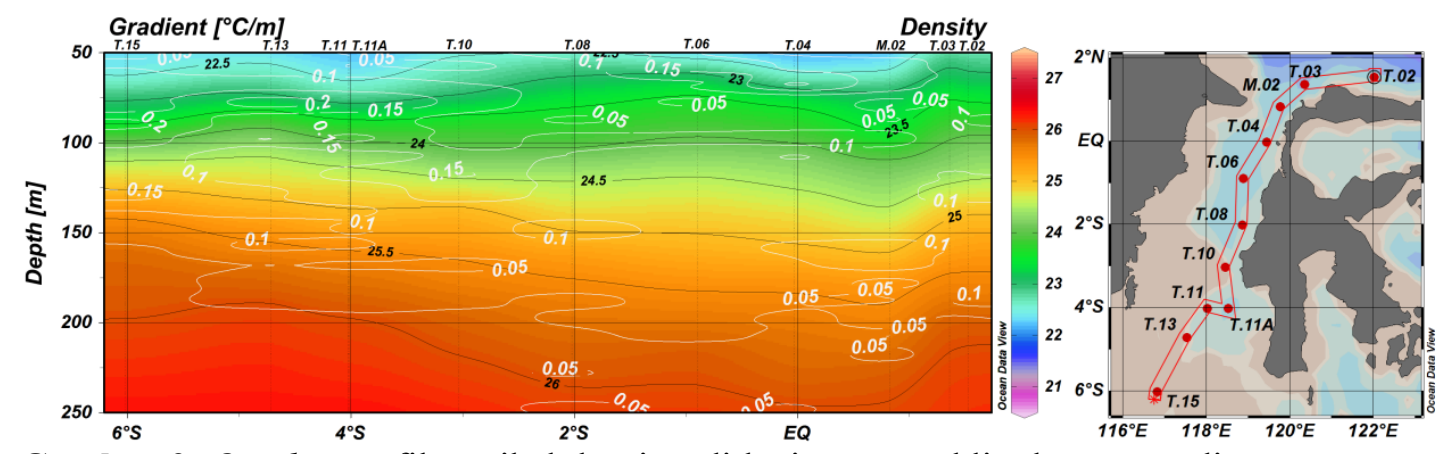

Gambar 9. Overlay profil vertikal densitas di lapisan termoklin dengan gradien temperatur di lapisan termoklin

\section{PEMBAHASAN}

\section{Gradien Temperatur}

Variabilitas nilai gradien temperatur bergantung pada temperatur batas atas dan batas bawah lapisan termoklin dan ketebalan lapisan termoklin. Gradien temperatur berbanding terbalik dengan 
ketebalan lapisan termoklin. Korelasi antara gradien temperatur dan ketebalan lapisan termoklin adalah semakin tebal lapisan termoklin maka gradien temperaturnya semakin kecil (Gambar 3). Hal ini diperkuat dengan perhitungan nilai korelasi antara gradien rata-rata temperatur dengan ketebalan lapisan termoklin yang bernilai $-0,81$ (Gambar 3). Nilai negatif menandakan bahwa antara gradien rata-rata temperatur dan ketebalan lapisan termoklin memiliki hubungan berbanding terbalik (Gambar 3). Nilai gradien rata-rata temperatur terbesar yang terdapat di stasiun Timit 15 diduga disebabkan karena selisih temperatur batas atas dan batas bawah lapisan termoklin yang besar, namun ketebalan lapisan termoklin nya tipis.

\section{Lapisan Homogen dan Lapisan Termoklin}

Variabilitas ketebalan lapisan homogen pada setiap stasiun dipengaruhi oleh beberapa faktor seperti : tekanan angin, pemanasan matahari dan partikel yang membatasi penetrasi bahang di kedalaman (Hasse dan Dobson, 1986). Berdasarkan hasil, stasiun yang terletak di perairan lebih tertutup (terhalang oleh Pulau Kalimantan dan Pulau Sulawesi) memiliki ketebalan lapisan homgen yang kecil (Gambar 4). Hal ini disebabkan karena lemahnya pengaaruh angin yang bertiup. Angin yang bertiup di atas permukaan laut memberikan gaya friksi terhadap air laut yang akan menyebabkan pergerakan massa air dan terjadinya pengadukan air laut. Semakin besar kecepatan angin yang berhembus di atas permukaan air laut semakin kuat pengadukan massa air yang selanjutnya akan meningkatkan ketebalan lapisan homogen.

Menurut Boston (1966), kedalaman lapisan homogen efektif untuk mendefinisikan kedalaman batas atas lapisan termoklin. Kedalaman batas atas lapisan termoklin pada stasiun yang berada di bagian Utara Selat Makassar memiliki nilai kedalaman batas atas yang besar yaitu 67,5 m (Gambar 4). Hal ini diduga disebabkan oleh adanya pengaruh langsung dari Samudra Pasifik, yaitu adanya pengaruh transport volume yang menyebabkan batas atas lapisan termoklin menjadi dalam. Menurut Gordon et al. (2000) bahwa antara variabilitas lapisan termoklin dan variabilitas transport volume ke selatan, yaitu dari Samudra Pasifik ke Samudra Hindia ternyata memiliki hubungan atau korelasi yang tinggi yaitu saat transport volume besar akan menyebabkan lapisan termoklin terdesak ke lapisan yang lebih dalam.

Terjadinya variasi kedalaman batas atas lapisan termoklin di setiap stasiun pengamatan diduga karena adanya aktivitas gelombang internal. Pada saat puncak gelombang internal melewati kolom perairan, lapisan homogen akan termampatkan dan akan menjadi lebih tipis. Hal berbeda jika lembah gelombang internal melewati kolom perairan maka lapisan homogen akan menjadi lebih tebal. Hal ini dijelaskan oleh Li et al. (2000), bahwa gelombang internal merupakan salah satu penyebab perbedaan tingkat ketebalan lapisan homogen selain faktor kecepatan angin yang bertiup diatas permukaan laut.

Sebaran batas bawah lapisan termoklin di setiap stasiun memiliki nilai yang berbeda-beda. Perbedaan kedalaman batas bawah lapisan termoklin terjadi diduga dipengaruhi oleh adanya pergerakan massa air dalam yang mempunyai temperatur yang rendah dan salinitas tinggi. Menurut Wyrtki (1961), massa air yang berada di lapisan termoklin Selat Makassar ini berasal dari Samudra Pasifik Utara yang terdiri dari Massa Air Subtropik Pasifik Utara (Northern Subtropical Lower Water) pada kedalaman 120-200 m dengan temperatur massa air 23-15 ${ }^{\circ} \mathrm{C}$ dan Massa Air Menengah Pasifik Utara (Northern Intermediate Water) pada kedalaman 250-400 m dengan temperatur massa air 12-9 ${ }^{\circ} \mathrm{C}$. Wyrtki (1961) berpendapat bahwa batas bawah lapisan termoklin dibatasi oleh adanya kedua massa air tersebut.

Nilai sebaran batas bawah dan batas atas lapisan termoklin menciptakan selisih kedalaman atau dapat diketahui sebagai ketebalan lapisan termoklin. Perbedaan nilai ketebalan lapisan termoklin terjadi diduga dipengaruhi oleh adanya proses-proses dinamika yang sering dijumpai pada daerah arus dan sirkulasi massa air, di daerah tersebut massa air yang panas dapat melakukan intrusi ke bawah sehingga menyebabkan batas bawah lapisan homogen menjadi lebih tebal dan letak lapisan termoklin menjadi lebih dalam dan ketebalannya menjadi tipis.

\section{Distribusi Suhu}

Suhu permukaan laut daerah utara Selat Makassar lebih hangat dari pada daerah selatan Selat Makassar (Gambar 4). Nilai suhu pada lapisan termoklin di selatan Selat Makassar memiliki nilai suhu 
rendah lebih dangkal dari titik-titik stasiun yang berada di utara Selat Makassar (Gambar 5). Hal ini dikarenakan suhu lapisan permukaan di utara Selat Makassar yang lebih hangat dari suhu lapisan permukaan di selatan Selat Makassar sehingga mempengaruhi lapisan dibawahnya.

\section{Distribusi Salinitas}

Salinitas permukaan di selatan Selat Makassar lebih tinggi dari daerah tengah dan utara Selat Makassar (Gambar 6). Jika dikorelasikan dengan distribusi suhu permukaan laut di daerah selatan Selat Makassar (Gambar 4), maka diduga daerah tersebut merupakan daerah terjadinya fenomena upwelling. Beberapa indikator terjadinya fenomena upwelling yaitu temperatur yang lebih rendah dari sekitarnya, salinitas yang datang dari bawah, konsentrasi salinitas yang lebih tinggi dari sekitarnya, jumlah nutrien yang tinggi, klorofil yang tinggi namun sampai pada fenomena upwelling masih dibutuhkan jeda (Kunarso et al., 2011).

\section{Distribusi Densitas}

Distribusi vertikal densitas terhadap kedalaman berbeda dengan distibusi suhu terhadap kedalaman dimana semakin bertambah kedalaman maka nilai densitas semakin bertambah. Distribusi densitas berbanding terbalik dengan distribusi suhu namun berbanding lurus dengan distribusi salinitas. Menurut Tomczak, M (2001), densitas air laut bergantung pada temperatur (T), salinitas (S) dan tekanan(p) dimana kebergantungan ini dikenal sebagai persamaan keadaan air laut (Equation of State of Sea Water).

\section{KESIMPULAN}

Selat Makassar memiliki ketebalan lapisan homogen (batas atas lapisan termoklin) lebih tebal di perairan yang terletak lebih dekat dengan perairan terbuka sebagai akibat dari pengaruh angin dan pergerakan massa air. Sebaran batas bawah lapisan termoklin lebih dangkal terdapat di perairan yang lebih tertutup (terhalang Pulau Kalimantan dan Pulau Sulawesi). Variabilitas kedalaman batas bawah lapisan termoklin dipengaruhi oleh sirkulasi massa air dalam yang mempunyai suhu rendah dan salinitas tinggi. Ketebalan lapisan termoklin cenderung lebih tebal di perairan utara Selat Makassar. Gradien rata-rata temperatur berbanding terbalik dengan ketebalan lapisan termoklin. Stasiun dengan gradien rata-rata temperatur kecil memiliki ketebalan lapisan termoklin yang besar.

Distribusi suhu di permukaan laut Selat Makassar cenderung lebih hangat di utara Selat Makassar. Hal ini menyebabkan sebaran suhu di lapisan termoklin memiliki sebaran nilai suhu rendah lebih dangkal di selatan Selat Makassar. Nilai salinitas permukaan cenderung lebih tinggi di daerah selatan Selat Makassar. Hal ini diduga disebabkan karena pengaruh perairan di sekitarnya yaitu Laut Jawa dan Laut Flores. Nilai salinitas yang tinggi dan nilai suhu yang lebih rendah di selatan Selat Makassar merupakan indikator terjadinya upwelling. Distribusi densitas lebih dipengaruhi oleh distribusi suhu dimana keduanya memiliki hubungan keterbalikan.

\section{DAFTAR PUSTAKA}

Boston, N.J.E. 1966. Objective Definition of the Thermocline. Department of Oceanography College Station, Texas A\&M University, Texas, $38 \mathrm{p}$.

Tomczak, M dan J. S. Godfrey. 2001. Regional Oceanography : An Introduction. Butler \& Tanner Ltd, London.

Gordon, A. L., and R. A. Fine. 1996. Pathways of Water Between the Pacific and Indian Oceans in the Indonesian Seas. Journal of Nature, 379(4):146- 149.

Kunarso, Hadi, S., Ningsih, N. S., Baskoro, M. S. 2011. Variabilitas Suhu dan Klorofil-a di Daerah Upwelling pada Variasi Kejadian ENSO dan IOD di Perairan Jawa sampai Timor. Jurnal Ilmu Kelautan, 16(3): 171-180.

Ross, D.A. 1970. Introduction to Oceanography. Prentice-Hall Inc, USA.

Sugiyono. 2009. Metode Penelitian Kuantitatif, Kualitatif dan R\&D. Alfabeta, Bandung.

Wyrtki, K. 1961. The Physical Oceanography of South East Asian Waters. Naga Report, University California Press, La Jolla, California, 2:195 p.

Stern, M.E. 1975. Ocean Circulation. Physics Academi Press, New York, 246pp. 
Nontji, A.1987. Laut Nusantara. Djembatan, Jakarta.

Li, X., Colon, P.C. and Friedman, K.S. 2000. Estimating Oceanic Mixed Layer Depth From Internal Wave evolution Observed From RADARSAT-1 SAR. Journal of John Hopkins APL Technical Digest, 21(1):130-135.

Gordon, A.L., A. Ffield, K. Vranes, S.L. Garzoli and R.D. Susanto. 2000. Temperature Variability within Makassar Strait. Journal of Geophysical Research Letters, 27(2): 237-240.

Hasse, L. And F. Dobson. 1996. Introductory Physics of the Atmosphere and Ocean. Reidel Publication, Dordrecht, Netherlands.

Sugiyono. 2011. Metode Penelitian Pendidikan. Alfabeta, Bandung.

Song, L.M., Y. Zhang, \& Y. Zhou. 2007. The Relationship Between the Thermocline and the Catch Rate of Thunnus obesus in the Tropical Areas of the Indian Ocean. IOTC Proceeding-WPTT14-rev1, 1-13.

Sugiyono. 2009. Metode Penelitian Kuantitatif, Kualitatif dan R\&D. Alfabeta, Bandung.

Wyrtki, K. 1987. Indonesian Through Flow and The Associated Pressure Gradient. J. Geophys. Res. Oceans, 92(C12):12941-12946.

Fieux, M.C., E. Andrie, A.G. Charriaud, N. Ilahude, R. Metzl, Molcard and J.C. Swallow. 1996. Hydrological and chlorofluoro-methane Measurements of the Indonesian Throughflow Entering the Indian Ocean. Journal of Geophysical Research, 101(C5):12433-12454. 